LEITURA - LITERATURA E UTOPIA, n. 32, p. 187-213, jul./dez. 2003.

\title{
NOTAS SOBRE NATUREZA E ARTIFÍCIO NA ILHA DOS HERMAFRODITAS
}

\section{Ana Cláudia Romano Ribeiro}

Resumo: A Ilha dos Hermafroditas, utopia francesa publicada em 1605, relata a vida dos hermafroditas, que têm seu código moral baseado na realização de empreendimentos prazeirosos e vantajosos através do artifício, manifestado pela sofisticação excessiva das exterioridades. Os syredonnes vivem em um estado de cultura avançado, em que a natureza encontra-se sempre oportunamente modificada: a ilha dos hermafroditas, longe de ser um paraíso selvagem, é um lugar altamente civilizado. Nela, o artifício encobre aquilo que se quer dissimular, o interesse individual, e se traduz na preocupação que mostram os hermafroditas em incrementar a sua aparência, a dos objetos que fazem parte de sua vida, na sua linguagem e nas suas leis. É o que mostraremos neste artigo e na apresentação de trechos traduzidos dessa utopia.

Palavras-chave: Utopia Francesa. Antiutopia. Hermafrodita. Natureza. Artifício.

A Ilha dos Hermafroditas, publicada em Paris em 1605, obra geralmente classificada junto a panfletos e à literatura polêmica, inaugura o gênero literário utópico na França de maneira original, já que também contém em si a primeira antiutopia francesa ${ }^{1}$. O nobre

Ana Cláudia Romano Ribeiro é professora da Aliança Francesa de Campinas-SP. Em seu trabalho de mestrado, "A Ilha dos Hermafroditas : viagem à França especular de Henrique III", realizado no Departamento de Teoria e História Literária do Institutos de Estudos da Linguagem Unicamp, estudou e traduziu para o português a Ilha dos Hermafroditas, utopia francesa atribuída a Artus Thomas. Atualmente, sob a orientação do Prof. Dr. Carlos Eduardo Ornelas Berriel, faz seu doutorado na mesma instituição e prepara um estudo e uma tradução para o português de $L a$ Terre Australe Connue, de Gabriel de Foigny.

1 O principal estudioso da Ilha dos Hermafroditas é Claude-Gilbert DUBOIS, que preparou uma edição dessa obra acompanhada de um estudo e de notas explicativas: L'Isle des Hermaphrodites. Édition, introduction et notes par Claude-Gilbert DUBOIS. Genève: Droz: 1996. 
francês Artus Thomas, sieur d'Embry, freqüentador da corte do último Valois, teria sido seu autor. No texto, que não segue a estrutura paradigmática da Utopia de Thomas Morus, encontram-se modos narratológicos variados: uma antiutopia de teor satírico, na qual o narrador apresenta um viajante que descreverá a ilha dos hermafroditas e transcreverá suas leis, além de três escritos heréticos: um poema panfletário contra os hermafroditas, um discurso apologético - a utopia propriamente dita - em que estão expostos os princípios fundadores de uma sociedade de inspiração cristã, todavia sem filiação a um credo religioso, e, por fim, um discurso que trata da relação entre alma e corpo.

Para Pierre Bayle, a Ilha dos Hermafroditas é uma sátira engenhosa da corte de Henrique III, rei que se vestia de modo efeminado e vivia cercado de mignons, com quem mantinha uma relação confidencial. $O$ alcance desse texto, de grande riqueza simbólica, vai, porém, além do tema sexual. Sua principal chave de leitura é a figura do hermafrodita, que, saído da área da teratologia médica, toma valor simbólico e pode ser transposto a diferentes áreas, especialmente à ideologia e à política, designando uma forma de oportunismo moral, econômico, filosófico e político, encoberto por uma ambigüidade de conduta e de discurso.

Interessaremo-nos particularmente, neste artigo, pela primeira parte da Ilha dos Hermafroditas, em que o narrador conta a história de um viajante que, após naufragar em uma ilha desconhecida povoada por hermafroditas, situada nos caminhos marítimos que levam a Lisboa, descobre sua natureza exuberante e seu suntuoso palácio. Nele, encontrará os syresdonnes, cortesãos sexual e moralmente ambíguos, cuja aparência, comportamentos e leis descreverá. Esses cidadãos, que nada têm da virtude nem da frugalidade exemplares das utopias de Morus ou de Campanella, têm seu código moral baseado na realização de empreendimentos prazeirosos e vantajosos através do

Ele também dedicou a esta utopia vários de seus artigos. Ver Referências. Uma tradução de dois trechos da antiutopia, "Ordenanças sobre o fato da religião" e "Artigo de fé dos hermafroditas", foi publicada, juntamente com uma apresentação, em RIBEIRO, Ana Cláudia Romano. "A Ilha dos Hermafroditas (Paris, 1605) em seu ambiente histórico", em Revista Morus, n 1, Campinas, 2004, p. 147-165.. 
artifício, manifestado pela sofisticação das exterioridades. Os syredonnes vivem, portanto, em um estado de cultura avançado, em que a natureza encontra-se sempre oportunamente modificada: a ilha dos hermafroditas, longe de ser um paraíso selvagem, é um lugar altamente civilizado. Nela, o artifício encobre aquilo que se quer dissimular, o interesse individual, e se traduz na preocupação que mostram os hermafroditas em adornar a sua aparência, a dos objetos que fazem parte de sua vida, a sua linguagem e as suas leis. É o que mostraremos neste artigo e na apresentação de trechos traduzidos dessa utopia, que se encontram no anexo.

A vida dos habitantes da ilha dos hermafroditas caracteriza-se por uma excessiva preocupação com a aparência pessoal e com o aparato social, do qual fazem parte a ocultação por meio de máscaras e por outros artifícios, a dissimulação e o ritual. Artus Thomas descreve uma sociedade cuja vida em seu todo - a aparência física individual, o aspecto dos objetos, as regras de comportamento e as leis - baseia-se em artifícios, já que nada é deixado em seu estado natural. Empregamse as mais variadas técnicas para alterar a aparência física e incrementar tudo o que é percebido pelos sentidos: "trata-se de explorar os efeitos de uma ars naturans, que não é tomada no seu sentido renascentista de emulação da arte e da natureza, mas em seu sentido maneirista, de arte mais forte que a natureza, que acaba por recusá-la e substituir-se a ela",2 (DUBOIS, 1996, p. 24). Tal sensualidade não se refere àquela epicurista, ou ao racionalismo aplicado ao conhecimento da natureza, mas a um estado de cultura avançado cujo recurso ao artifício é indispensável. A natureza tem aqui pouco espaço, pois ela é manipulada e transformada: a arte dissimula a natureza.

Dubois vê nesse libelo uma crítica ao estetismo maneirista derivado do naturalismo renascentista. Nela, natureza e artifício, dois elementos centrais, contrapõem- se. A natureza deve ser entendida aqui em seu aspecto negativo: não como em Campanella (em cuja Cidade do Sol ela é potência organizadora de uma vida social harmônica), mas como fonte de comportamentos anti-sociais, porque instintivamente egoístas, naturalmente viciados. O uso da palavra

2 Todas as traduções são minhas. 
"natureza" não se funda em um naturalismo que busca a harmonia dos contrários. Os hermafroditas não traduzem os ideais universais do retorno à natureza e à liberdade. Estes ideais, na utopia de Artus Thomas, mascaram atitudes hipócritas, chamadas metaforicamente de "hermafródicas" nesse libelo. A natureza passa por uma elaboração insensata, representando assim o abandono sem entraves à força do desejo individual. Ressaltando os vícios advindos de um comportamento guiado por essa concepção de natureza, paradoxalmente elaborada por meio de artifícios, esse texto denuncia a subordinação dos princípios éticos a uma lei estetizada do interesse e do prazer.

$\mathrm{O}$ aspecto físico de seres e coisas na ilha dos hermafroditas

Para ilustrar a questão do artifício na aparência dos syredonnes, tomaremos três momentos da antiutopia em que são relatados, sucessivamente, o despertar do hermafrodita, os procedimentos de embelezamento da cabeça e a metamorfose de um pé.

O protagonista, ao penetrar no palácio, entrou em diversos cômodos e observou de perto o que neles faziam os hermafroditas. Em um deles, assistiu a uma extravagante cerimônia matinal do despertar, que, curiosamente, lembra a descrição feita pelo historiador Philippe Erlanger de um dia do rei Henrique III (ERLANGER, 1948, p. 28286). Ao final da manhã, misturando-se com os inúmeros criados que iam e vinham, o viajante ousou entrar em um cômodo ricamente mobiliado, enfumaçado e perfumado, com paredes revestidas de tecidos e tapeçarias, e descobriu janelas e leito cobertos com cortinas, que transgrediam assim a alternância natural do dia e da noite, segundo a vontade de quem estivesse deitado. Ouviu uma voz queixosa que reclamava ter sido acordado, mas não conseguiu ver o dono da voz, que estava escondido sob mantos, cobertas e cujo rosto estava coberto com uma máscara. Em seguida, viu "algo" ornado com um penteado feminino que os serviçais cobriram com um manto forrado e bordado com brilhos. Somente depois de algum tempo, o viajante descobriu que "aquilo" que ele vira era um hermafrodita, mascarado, enluvado e enfeitado com um penteado em forma de corneta, de quem os serviçais retiravam peças de roupas, levantavam tecidos que escondiam partes de seu corpo sem, no entanto, jamais 
desvendá-lo por inteiro. Compunha esse ritual uma série de objetos, como pratos cobertos, um vaso em forma de incensório, um recipiente contendo um caldo restaurador, iguarias em forma de rolo, e toalhas úmidas e secas para o asseio.

O hermafrodita está em constante representação. Com efeito, a descrição de seus atos assemelha-se à descrição de um espetáculo. Percebe-se a importância do verbo "ver" e de outros, semelhantes. Verdadeiro acontecimento, o cerimonial compõe-se de objetos que, quando não servem para encobrir, estão encobertos. A aparição do personagem hermafrodita se faz por ocultação: primeiramente, ele não é mais do que uma voz, sem corpo; em seguida, o que dele se vê são, sobretudo, diferentes camadas de coberturas e enfeites, que parecem esconder um objeto frágil e importante e suscitam uma interrogação sobre sua identidade. Assiste-se ao culto de um ser invisível em que os apetrechos usados dizem respeito mais à cerimônia da toalete, fim em si mesma, do que ao corpo do hermafrodita (DUBOIS, 1988, p. 311). O corpo existe enquanto suporte para que um conjunto de criados o vista, o enfeite, o cubra de camadas de máscaras, véus, tecidos, variadas peças de roupa, que constituem a verdadeira substância do seu ser desprovido de identidade e de personalidade.

Em outros cômodos, verdadeiros salões de beleza, os hermafroditas enfeitavam suas cabeças com a ajuda de aparelhos complicados, vapores e substâncias as mais diversas. Há um contraste marcante entre a sofisticação das operações estéticas realizadas, sugerindo quase um enigma, e seu caráter frívolo: para fazer um penteado que deixaria suas cabeças semelhantes a "um céu coberto de pequenas nuvens encarneiradas" usavam pequenas tenazes em brasa com as quais puxavam seus cabelos, tornados fumegantes; empoavam-se com um grande pompom de seda cheio de pó de arroz; faziam as sobrancelhas com uma pinça de ferro ou depilavam-nas com a ajuda de cera quente; maquiavam-se com cinábrio, que provocava pequenas inflamações avermelhadas, ironicamente comparadas a uma "mina de rubis"; higienizavam gengivas e dentes com um pó branco, usando para isso os dedos, e introduziam na gengiva falsos dentes feitos de ossos presos por ferros bem finos; mudavam a cor da barba, que cortavam e perfumavam; por fim, usavam as tenazes acima citadas para esculpir o bigode em forma de calha, invenção "que não 
era má no inverno, principalmente para aqueles que querem observar as regras de asseio".

Após o relato desse longo e laborioso processo de embelezamento da cabeça, são descritas de maneira detalhada todas as etapas pelas quais passa um destes hermafroditas quando se veste, ajudado por criados e segundo uma ordem precisa de peças de roupa e de ornamentos. Também aqui nota-se uma preocupação em mudar a natureza, através de complicados artifícios que têm apenas um objetivo estético, especialmente na passagem em que se transforma um "pé gordo" hermafrodita em um pequeno pé, semelhante a uma delicada pata de um elegante cão de caça, adornado com um grande laço imitando uma rosa.

A aparência dessa natureza, paradoxalmente cuidada, rebuscada, retocada, remodelada, não-natural, pode ser vista nos menores detalhes da vida no palácio. As comidas servidas nos festins e os elementos de decoração da mesa têm seu aspecto dissimulado, parecem ser o que não são, iludindo o espectador dessa espécie de grande espetáculo teatral: a toalha parecia um riacho ondulando ao sabor do vento; em outro ponto da mesa, uma outra toalha, muito delicada, dava uma impressão de espaço vazio; os guardanapos tinham forma de frutas e de pássaros; os pratos estavam todos cobertos; as carnes estavam irreconhecíveis de tanto que foram "moídas, cortadas e fantasiadas"; as frutas eram aquilo cuja forma mais havia sido "fantasiada", apresentando-se como "untagens, geléias líquidas e outras invenções".

A espada, objeto nobre, também sofre uma transformação e, de símbolo de valores cavalheirescos, torna-se simples objeto decorativo com funções sensuais. Atributo de uma aristocracia feudal que, em complexo processo, vinha se transformando em aristocracia de corte, uma nobreza cujas bases estavam mudando; o uso que dela fazem os hermafroditas mostra que ela perdeu seu sentido glorioso, tornando-se mero adereço $o^{3}$ já não eram mais usadas para lutas, dadas

3 Sobre a constituição da sociedade de corte francesa, ver ELIA.S, Norbert. "Formação e evolução da sociedade de corte em França", em A sociedade de corte. Lisboa: Estampa: 1995, p. 121-181. 
a beleza e a delicadeza com que foram ornadas, servindo para a decoração ou para quando seu senhor quisesse mostrar-se corajoso.

Como foi visto até aqui, no cerimonial que resume a vida dos hermafroditas, tudo é artifício. A aparência, os gestos e o comportamento desses personagens são estetizados, são manifestações formais que fazem parte de um ritual repetido diariamente de maneira minuciosa. $\mathrm{O}$ artifício estende-se ao recurso material que faz o cortesão hermafrodita parecer o que não é, e que desvia os sentidos dos objetos que compõem sua existência, é o que embeleza um vazio e mascara uma ausência, à maneira dos ornamentos maneiristas. O cuidado excessivo com a superfície revela a preocupação com uma permanente e ambígua demonstração: é ocultando que se mostra. $\mathrm{O}$ hermafrodita existe através da formalização estetizante. Com efeito, os hermafroditas do palácio se parecem todos entre si, não têm profundidade psicológica nem possuem singularidades individuais, são personagens vazios (DUBOIS, 1987, 1988).

\section{A linguagem hermafrodita}

Os hermafroditas obedecem a regras que dizem respeito à linguagem, esparsas nos diversos itens de sua legislação, nem sempre explícitas. Sua língua, assim como o epônimo habitante da ilha, tem gênero duplo, entrando em um "sistema geral de simbolização que determina o modo de expressão verbal como modalidade particular de um modo de vida" (DUBOIS, 1988, p. 311).

Os hermafroditas conhecem também o grego, o latim, alguns deles o italiano, além de outras línguas. O viajante e seus interlocutores comunicam-se em italiano e em latim, mas suas conversas são transcritas em francês, língua vernácula. Trata-se de uma corte semelhante à corte francesa, na qual a língua italiana, em moda na corte francesa, que recebia artistas italianos desde Francisco I, tornou-se ainda mais presente por influência de Catarina de Medicis e, depois, de Maria de Medicis.

$\mathrm{Na}$ linguagem hermafrodita, assim como no que concerne à aparência física, há uma constante dissociação entre o manifesto e o escondido, gerando comportamentos e discursos ocultados por um código secreto. Assim, a divisa "Todos os acordos" (A tous accords), escrita na página inicial dessa utopia e acompanhada do desenho de 
um hermafrodita, simboliza um acordo superficial que não vai além da palavra, dissimulando a duplicidade no plano pessoal e no político.

A escolha das palavras obedece ao critério da sofisticação e tem como princípio a formação de uma elite de iniciados diferenciada dos profanos, que não conhecem a linguagem codificada hermafrodita. É grande a preocupação em manter secreta a linguagem da elite. Em caso de banalização do vocabulário, os hermafroditas criam novos termos, para que haja sempre uma distância entre a língua do vulgo e aquela dos seletos hermafroditas. Ou seja, "o hermafrodismo aplica à linguagem uma política de privilégios, como aquela que existe no vestuário e no modo de vida no cotidiano dos aristocratas" (DUBOIS, 1988, p. 312).

Dubois discerne, no código lingüístico, as mesmas características do código que rege a indumentária e nota que é possível ler os termos do vestuário como metáforas da linguagem (1988, p. 314). Assim, quando uma ordenança diz que todos podem vestir-se segundo sua fantasia, subentende-se que também a palavra pode ser usada como se queira, segundo o capricho de cada um. A palavra "invenção", tirada do vocabulário da retórica, aplica-se, na Ilha dos Hermafroditas, ao vestuário e vice-versa: a inventio resulta de uma dispositio elaborada dos argumentos. Se está dito que um traje deve ser opulentamente enfeitado, sem decência nem necessária concordância com o estado social de um hermafrodita, compreende-se que a palavra deve ser usada de maneira pedante e de modo a iludir, "pois nesta ilha, o hábito faz o monge, e não o contrário", tanto quanto as "flores" da retórica hermafrodita servem "para sustentar ou para induzir à mentira".

Vimos, anteriormente, como os exagerados cuidados dedicados à toalete, à indumentária e aos tratamentos para embelezar indicam o valor da superfície do corpo e a importância dada a sua ocultação. Na linguagem dos hermafroditas, observa-se um procedimento similar que privilegia os adjetivos em detrimento dos substantivos: "estas pessoas de qualidade privilegiam a qualificação" (DUBOIS, 1988, p. 313). O substantivo permanece oculto por uma longa lista de atributos. Nesse procedimento, vemos a antecipação do desenvolvimento futuro da préciosité, linguagem preciosa que usa abundantemente qualificativos e advérbios, que definem qualidades e maneiras. O beau langage é tratado segundo a mesma lógica: 
desaparece a ligação entre forma e conteúdo, resta somente o malabarismo verbal, o virtuosismo formal, o uso amaneirado da linguagem (DUBOIS, 1988).

\section{As ordenanças da Ilha dos hermafroditas}

Grande parte dessa antiutopia consiste em um enunciado de regras que parodiam um código jurídico. Nele, os menores detalhes dos atos da vida dos hermafroditas estão codificados segundo disposições precisas, representativas de uma etiqueta, organizadas em seis partes: Ordenanças sobre o fato da religião, acompanhada dos Artigos de fé dos hermafroditas, de extremo materialismo, No que concerne à justiça e aos oficiais do estado, No que concerne à polícia, No que concerne às relações sociais e Leis militares. O texto é composto de um conjunto de permissões, proibições, prescrições e de negações de interditos. Transcreveremos abaixo alguns exemplos do conteúdo de cada um dos itens:

1) "Ordenanças sobre o fato da religião". Os hermafroditas não acreditam em outra vida além da terrena; sua religião é voltada para o prazer e para a volúpia e, em seus cultos, reverenciam Vênus, Baco e Cupido. As outras religiões são toleradas. Consciência, temperança e arrependimento são considerados coisas vãs e frívolas. A boa aparência é a virtude mais prezada: os sentidos são os mestres da existência. Deve haver somente belas palavras e belas promessas, sem obrigação de realizá-las. Os eclesiásticos poderão vender objetos sagrados, ignorar a santa escritura e se absterem de instruir aqueles de quem se ocupam.

2) "Artigo de fé dos hermafroditas". Nesse artigo, composto de oito itens, é dito que os hermafroditas ignoram a criação, a redenção, a justificação, a danação, o juízo final, a Providência e a eternidade. As únicas divindades que honram são Amor e Baco, e o único paraíso que almejam é o da volúpia temporal, reconhecida pelos sentidos. O único espírito no qual acreditam é aquele persuadido pelas paixões, visível nas paixões e afeições.

3) "No que concerne à justiça e aos oficiais deste estado". O homicídio, o incesto, o matricídio, parricídio, o fratricídio e o tráfico de crianças são permitidos, desde que, em troca, se alcance uma boa recompensa. Raptos e estupros são estimulados, quando quem os sofre 
ocupa uma posição inferior. Pode-se pegar emprestado sem devolver, usurpar e explorar os inferiores. Oficiais da justiça e os responsáveis pelas finanças deverão ser corruptos, favorecer a quem bem entenderem, usarem o tempo como quiserem, devendo ser generosamente subornados.

4) "No que concerne à polícia". Os reformadores e oficiais de polícia aceitarão falsificações diversas, desde que devidamente recompensados. Permitirão todos os discursos difamatórios contra o Príncipe e contra o Estado. Durante os anos em que o trigo e o vinho forem escassos, será permitido estocá-los e somente em último caso vendê-los (a um preço alto). Aqueles que quiserem defender interesses públicos serão desencorajados e obterão o contrário do que desejarem. Deve-se aparentar riqueza maior do que aquela que se tem, através do luxo de móveis e de festins. Calúnia e traição são sinais de boa reputação e de gentileza de espírito.

5) "No que concerne às relações sociais". Deve-se fingir ser agradável, belo e discreto, nas ocasiões em que houver intenção de enganar alguém. Em outros momentos, dever-se-á ser falso, hipócrita, orgulhoso, falar muito de si mesmo e impedir os outros de se manifestarem. As amizades serão ditadas pelo interesse e pela ingratidão, considerados gentilezas de espírito. Os melhores oradores escarnecerão das coisas santas. Serão tidos como gente valorosa aqueles que gastarem mais do que possuem e que se exibirem como se fossem ricos. Acreditar que a inteligência e a razão devem guiar a vontade será considerado uma ilusão.

6) "Leis militares". A escória do povo será escolhida para constituir o exército, já que a guerra é o único meio de enriquecerem facilmente. Os que matarem covardemente os inimigos serão estimados. Seus exercícios consistirão em, notadamente, correr atrás da vaca, bater o tambor, fazer o inventário dos bens que se encontram onde eles estão hospedados, combater a honra das jovens e mulheres. Os soldados farão reviver as antigas bacanais e darão mais goles do que pancadas. Chefes e soldados devem gabar-se de atos de valentia imaginários.

Para Dubois, essas partes têm a forma de uma listagem feita nos moldes dos códigos religioso, civil e militar, escrita em linguagem preciosa, cujo princípio gerador é a ironia, e que se exprime por 
paradoxos e pela inversão do modelo jurídico (1996, p. 27). De fato, A Ilha dos Hermafroditas pode ser vista como uma sátira que apresenta exatamente o contrário do que poderiam desejar as diversas instâncias da vida social, mostrando um mundo cuja ordem das coisas está invertida - do sexo de seus habitantes as suas leis - "convergindo no que poderíamos chamar de 'ordem barroca': estes jovens aparecem assim como relíquias de uma ordem mais antiga, em estado de decadência por suas hipertrofias quanto às maneiras, os resíduos de um maneirismo de corte no terreno de reconstrução do Estado e da Igreja" (DUBOIS, 1996, p. 25).

A base das ordenanças é tripla: o prazer, a liberdade e o lucro. O comportamento ideal do hermafrodita consiste em usar a liberdade para tirar o máximo proveito da realização do próprio prazer, portanto, visando alguma forma de lucro. Em outras palavras, a regra subentendida a toda a legislação traduz-se em um liberalismo sem limites que equivale a promover ganhos - de toda espécie - reservados a uma classe privilegiada. O lucro é o princípio que rege a legislação e leva ao paroxismo formulações hedonistas e liberais. A liberdade palavra que aparece inúmeras vezes no texto - para realizar o desejo individual vigora em diferentes setores da vida, particularmente no setor econômico, em que não há obstáculos de ordem ética para qualquer empreendimento. Desse modo, tal lei "selvagem" cria uma imagem de natureza muito diversa daquela edênica e idílica, que norteia as utopias fundamentadas em uma imagem maternal de natureza.

Na Ilha dos Hermafroditas, o recurso à natureza, que justifica o desejo instintivo, traduz-se em recusa de princípios e leis que regem comportamentos amplamente aceitos, de inspiração cristã, como os princípios dos dez mandamentos, os interditos sociais tradicionais e os usos que a tradição tornou naturais. Porém tal recusa se realiza mediante o artifício de um conjunto de regras, em que as práticas de prazer estão catalogadas e regulamentadas de modo preciso e extravagante, engendrando uma nova lei, carnavalesca e incoerente, que se aplica a todas as ações dos hermafroditas, até mesmo às mais banais. Para realizar o desejo, deve-se passar por uma lei que o mascara e permite sua realização, desde que isso se faça de maneira indireta, complicada e por meio do artifício de uma legislação invertida. Ou seja, a natureza é usada para justificar o desejo, mas esse 
desejo só pode se realizar de maneira controlada, mediante uma "lei transgressora", que não é mais do que um procedimento pelo qual se procura disfarçar atitudes "naturais". Há nisso uma contradição central: a liberdade absoluta dá ensejo a uma regulamentação estrita, em que abandonar-se ao desejo não significa transgredir, mas sim uma obrigação.

Dubois coloca em paralelo o "culto desenfreado" da satisfação hermafrodita e o "culto frenético" do desejo em Sade: "este culto desenfreado constitui, após o naturalismo renascentista fundado sobre a harmonia dos opostos, a mesma inflexão perversa do culto frenético sádico do desejo - este também justificado na natureza, segundo um imaginário que hipertrofia e inverte a concepção de natureza do Iluminismo" (1996, p. 34-5). Além disso, tanto em Sade como em Artus Thomas, o desejo segue uma codificação, "é o nó do complexo: um cadinho de contradições onde a liberdade absoluta leva a uma estrita regulamentação, onde o abandono ao desejo se metamorfoseia em obrigação, onde a via da satisfação passa por aquela de uma jurisdição" (1996, p. 35).

O resultado da lei é a acomodação à lei do lucro e ao desvio. Toda irregularidade torna-se um componente da regra. O princípio dessa legislação é a oposição entre o ser e o parecer, entre o funcionamento da regra e seu desregramento sistemático (DUBOIS, 1987, p. 23). Comparativamente, o que, no campo da ética, leva a uma perversão, no campo da estética, leva à anamorfose, distorção da forma que gera o paradoxo, semelhante às criações maneiristas que esvaziam a norma de seu conteúdo "por hiperbolização de seu funcionamento até o absurdo, o desregramento, a anormalidade" (1988, p. 34).

Há uma marcada ironia no texto: a lei natural e a regra de liberdade enunciadas provocam a negação do equilíbrio social e uma injusta repartição dos bens. As leis hermafroditas são uma paródia das leis - não enunciadas - do liberalismo desmesurado, que favorece a concentração de riquezas e de poderes em poucas mãos. A paródia dessas leis denuncia suas conseqüências socialmente nefastas. A legislação desse Estado, fundada sobre ganhos indevidos e seguindo uma lógica de inversão de sentidos, mostra que, na Ilha dos Hermafroditas, liberdade e privilégio estão vinculados. 
Nas leis dessa ilha singular, há uma tensão entre natureza e liberdade, colocadas em posição ambivalente. Dubois vê nessa contradição uma denúncia da atitude intelectual e moral do hermafrodismo como "pecado de lógica" presente na estética e na política do século XVII. A atitude intelectual do hermafroditismo caracterizar-se-ia pela "superposição de concepções contraditórias concernindo às noções de natureza e de liberdade" que se encontram em dois campos estreitamente ligados: a estética e a política (1988, p. 29).

O naturalismo culturalizado que lemos nas ordenanças hermafroditas expressa a contradição na qual vive essa sociedade, que se inclina, ao mesmo tempo, à natureza e à recusa da lei natural. A contradição entre o recurso à natureza como justificativa para a satisfação total dos desejos, que, no entanto, só podem se realizar mediante artifícios, e o desprezo pelas regras comuns de relação caracteriza o hermafroditismo como uma forma de dandismo, na qual a ação e as relações entre indivíduo e coletividade estão submetidas a regras estéticas:

Esse sentimento estético da vida, muito particular porque é dominado pelo ritual, pelo cerimonial, pelo culto da aparência, pela preocupação obsessiva com o detalhe e com a etiqueta, determina uma atitude narcisista, no plano individual, e egoísta, no plano social, onde se encontra a mesma ambivalência que nas funções atribuídas aos termos de natureza e de liberdade (DUBOIS, 1988, p. 29).

Segundo Dubois, o liberalismo desmedido acompanhado de manobras maquiavélicas caracterizará a política de Sully e de Colbert: “ordem, centralização, protecionismo, expansionismo mercantil. É a política econômica do que é convencionalmente chamado, desde J. A. Maravall, 'o Estado barroco'” (1988: 39). A Ilha dos Hermafroditas é mais do que a referência a um tempo passado, da corte de Henrique III, e a presença da figura do hermafrodita é mais do que uma moda passageira. A obra possui também um valor mais geral, de panfleto contra o que resta de um naturalismo corrompido, de forma decadente, que ataca um materialismo tido como deformado e um maneirismo que se traduz em "efeitos de obliqüidade e de perversão de valores", semelhante aos procedimentos da anamorfose, porém, aplicada à moral (DUBOIS, 1988). 


\section{ANEXO DE TRECHOS TRADUZIDOS}

\section{O aspecto físico de seres e coisas n'A ilha dos hermafroditas}

Assim continuando meu caminho, subi cerca de oito degraus da escadaria, ao final dos quais encontrei à mão esquerda uma porta aberta, pela qual entravam alguns homens, um dos quais portava um tecido e uma travessa dourada, um outro tinha um prato coberto, e como eram aproximadamente onze horas da manhã, pensei que fosse o almoço do senhor do lugar, que julgava muito mecânico, visto a sublime magnificência da residência e a multidão daqueles que estavam a seu serviço. Misturei-me então bastante ousadamente dentre estes, que não me recusaram a entrada no quarto; pois, pelo que soube depois, ela era completamente livre quando era dia, que aí nunca começava a despontar não fossem ao menos dez horas. Assim que pus os pés no quarto, senti o mais suave perfume que fosse possível imaginar, e tão logo vi um pequeno vaso em forma de incensório em Mosaico, do qual saía o vapor que enchia todo o lugar. Este quarto era muito magnificamente atapetado, e os móveis eram muito ricos e preciosos; mas como eu queria ver o paradeiro da minha companhia, não me deleitava tão particularmente a considerá-los por hora. Eu vi então que eles iam direto para um leito bastante largo e espaçoso, que com o espaço que deixava entre ele e a parede ocupava boa parte do quarto. Tão logo estes, tendo todos a cabeça descoberta, detiveram-se em direção dos pés da cama, esperando que um deles puxasse o cortinado; mas aquele que estava no leito começou a se queixar que o acordaram em sobressalto e que era demasiado cedo; os seus se escusaram o melhor que puderam e, entreabrindo um pouco as janelas, fizeram-lhe ver que o Sol estava alto. Ele então, ainda sonolento, sentou-se, e tão logo the colocaram sobre os ombros um pequeno manto de cetim branco recamado com brilhos e forrado com um tecido semelhante à fazenda de seda. Eu ainda não vira o que era que estava no leito, pois ainda não se viam as mãos nem o rosto; mas aquele que lhe colocara o manto logo veio retirar um tecido que lhe pendia muito baixo sobre o rosto, e remover uma máscara que não era de tecido nem da forma daquelas que usam de ordinário as Damas, pois ela era como de uma tela luzidia e muito justa, onde parecia que tivessem colocado alguma cera, contudo não cobria todo o rosto, pois era recortada em ondas na parte de baixo, de receio que isso ofendesse 
a barba que começava a algodoar de todos os lados; depois lhe descalçaram as luvas que tinha nas mãos, e que usara toda a noite, ao que pude julgar, em seguida um dos seus que parecia fazer-se de entendido mais que os outros lhe trouxe uma toalha com a ponta molhada, com a qual, tendo esfregado muito delicadamente a ponta dos dedos, apresentaram-lhe o caldo que haviam trazido, que na aparência tinha a forma de algum concentrado ou restaurador, que ele tomou até a última gota; depois do que lhe apresentaram num outro prato alguns doces cristalizados, feitos em forma de rolo, onde parecia haver carne misturada, dos quais, depois de ter comido três ou quatro, fez retirar o resto de diante de si, e então lhe trouxeram uma outra toalha molhada, com a qual, tendo ainda se lavado e se enxugado, deram-lhe suas luvas, que calçou em suas mãos; depois o criado de quarto, tendo-lhe recolocado sua máscara e abaixado sua corneta, tirou-lhe o manto; fiquei espantado que meu homem tenha se precipitado novamente no leito, e, após tê-lo coberto, fecharam novamente o cortinado, dizendo que ele ia tentar repousar ainda uma horinha. Eu acreditava, no início, que ele estava doente, mas vendo sua alegria, sua boa feição, e como comera com bom apetite, logo mudei de opinião ${ }^{4}$ (Grifos meus).

[...] mal entrara no quarto, quando vi três homens presos pelos cabelos por pequenas tenazes que eram puxadas por alguns pequenos braseiros, de sorte que víamos seus cabelos todos fumegantes. No início isso me assustou, e tive toda a pena do mundo para me impedir de gritar, pensando que lhes fizessem algum ultraje; mas quando eu os considerei mais de perto, reconheci que não lhes faziam mal algum. Pois um lia um livro, outro gracejava com um criado, e outro entretinha um que se dizia filósofo; diríeis que queriam fazer de seus cabelos como desses rolos de estamenha, de tanto que estavam enroscados entre as tenazes; e quando toda esta cerimônia estava acabada, suas cabeças pareciam um céu coberto de pequenas nuvens encarneiradas. Deste quarto entrava-se em outros, nos quais, por estarem abertos, via-se tudo o que neles se fazia; a alguns, eram

4 Em RIBEIRO, Ana Cláudia Romano. "A Ilha dos Hermafroditas": viagem à França especular de Henrique III, 2004, p. 141-142. 
retiradas as cordinhas com as quais seus cabelos estavam enroscados, a outros, sacudiam-lhes tanto a cabeça que se poderia pensar que se tratava de alguma árvore da qual se devesse fazer caírem frutas. Também outros havia a quem diríeis que fizeram uma pequena operação de cauterização. Cada um deles tinha vários homens em volta da cadeira onde estavam sentados, um desfazendo o que o outro fizera, outro segurando entre as mãos um grande espelho (um outro tinha em suas mãos uma caixa cheia de pó semelhante àquele de Chipre, com um grande pompom de seda que mergulhava nesta caixa, e empoava a cabeça do paciente). Quando isso terminava, vinha um outro tendo na mão um pequeno pincel de ferro do qual se servia para tirar a abundância de pelos das Sobrancelhas, e deixar aí somente um traço muito fino para fazer a arcada. [...] Enquanto toda esta cerimônia se fazia, eu via um no canto do quarto que, com um certo instrumento que eles chamavam sublimatórios, fazia exalar o mercúrio num certo vapor, o qual condensado e compactado ele vinha aplicar sobre as bochechas, Fronte, e Colo do Hermafrodita. Eu via outros que usavam certas águas com as quais o lavavam que tinham tamanho poder que elas podiam tornar delicada uma tez muito grosseira. É verdade que soube depois que elas tinham uma outra propriedade, a de que, após ter por um tempo clarificado a tez, elas faziam do rosto uma mina de rubis, por esse meio tornando um homem rico num instante. Eu pensava que a fricção de lábios seria a última cerimônia, mas vi naquele momento um outro pôr-se de joelhos diante dele e pegando-o pela barba, lhe fazia abaixar o maxilar inferior, depois, tendo molhado o dedo em não sei que água que se encontrava perto dele em uma pequena escudela de vidro, tomou um pouco de certo pó branco, com o qual esfregou-lihe as gengivas e os dentes, depois, abrindo uma pequena caixinha, tirou não sei que ossos, que fez-lhe entrar na gengiva atando-os com um ferro bem fino, dos dois lados por onde ele podia pegá-los. Aquele que lhe colorira as bochechas veio depois com uma pequena concha e um pincel na mão, do qual ele se serviu para mudar-lhe a cor da barba que estava quase da cor do fogo. Trouxeram uma outra certa toalha bastante clara, feita em forma de luvas, com a qual ele esfregou suas bochechas, que enchia e inchava a fim de fazer desbastar o pelo que the crescia em demasiada abundância. [...] Depois que isso estava feito, aquele que lhe enrolara o cabelo vinha com uma pequena ferramenta, que ele colocava no braseiro do qual falava acima, que lhe realçava tão bem os pelos sobre a boca, que vós 
teríeis dito uma goteira; e na verdade a invenção não era má no inverno, principalmente para aqueles que querem observar as regras de asseio. Eu via outros também a quem se ensaboava a barba com certas bolinhas, que lavavam depois com certas águas de cheiro ${ }^{5}$.

[...] um outro veio logo depois trazer um pequeno par de sapatos muito estreitos e de corte gracioso; eu ria comigo mesmo de ver tão pequenos calçados e não podia compreender na verdade como um pé grande e gordo podia entrar num tão pequeno sapato, já que a regra natural quer que o continente seja maior do que o conteúdo, e todavia aqui era o contrário: vós o teríeis visto dar grandes pancadas contra o chão e com seu movimento fazer tremer tudo o que estava sob ele; depois deram-lhe grandes pancadas contra a ponta do pé. Isso me fazia relembrar aqueles que querem representar alguma coisa em uma comédia. Pois eu via um homem com um joelho no chão e o outro no ar sobre o qual pusera uma perna, e bater com a mão, ora a ponta do pé, ora o calcanhar, depois, com uma certa pele, fazer entrar de modo justo o calçado, até o lugar onde devia ir. Certos grandes laços serviam depois para fazê-lo segurar mais firmemente, os quais eram feitos de modo que pareciam uma rosa ou alguma outra flor parecida. Coisa maravilhosa este pé, que me parecera tão grande antes de ser calçado; eu o julgava depois tão pequeno que dificilmente podia reconhecê-lo, e o teria quase tomado pelo pé de algum grifo. Eles diziam que tudo isso se fazia para a multiplicação dos corpos, que não é uma pequena ciência na natureza ${ }^{6}$.

Do outro lado desta mesa, havia uma grande cesta e nela vários tipos de pão: um feito, como dizem, com massa fermentada, o outro com massa triturada, um outro com levedura; um era fofo, estufado e salgado, o outro todo liso e sem sal; um era redondo, o outro longo; um feito com chifres, um menor, o outro um pouco mais gordinho. Por fim havia de todas as idades e de todas as espécies. Eles eram semelhantes somente em uma coisa, é que nenhum tinha sua

5 RIBEIRO, 2004, p. 142-144.

6 Idem, ibidem, p. 145. 
aparência natural, pois lhes haviam raspado tanto que não restava mais do que uma pequena casca muito delicada ${ }^{7}$.

A toalha era de um tecido muito graciosamente adamascado; mas porque neste país as coisas que estão em seu natural, qualquer grau de perfeição possam elas adquirir, não lhes são agradáveis se não estiverem fantasiadas, estivera dobrada de um certo modo que parecia muito um riacho ondulante que um pequeno vento faz docemente sobrelevar. Pois dentre várias pequenas dobras, via-se muitos tufos.

Sob esta toalha havia mais uma, simples, que era mais curta que aquela acima. Esta mesa estava guarnecida de pratos dos dois lados, excetuada a extremidade alta onde parecia haver um grande vazio, que no entanto não havia, como pude ver depois, havia, sim, uma pequena toalha dobrada de um outro modo ainda mais delicadamente que a precedente, que fazia que à primeira vista se julgasse que não havia nada embaixo. ${ }^{8}$

Os outros guardanapos que estavam em volta da mesa estavam fantasiados de vários tipos de frutas e pássaros. E quando eu me divertia considerando esta indústria (não sem admiração da perda de tempo que se fazia no exercício de uma coisa tão vã). ${ }^{9}$

Tão logo esta primeira toalha foi tirada, um gentil-homem servo veio colocar os pratos, todos cobertos, sobre esta mesa, de modo que estava repleta de carnes, sem que se soubesse o que nela havia. ${ }^{10}$

As carnes deste primeiro serviço foram tão moídas, cortadas e fantasiadas que estavam irreconhecíveis. Isto foi a causa de ter me limitado antes na consideração das ações do que a particularizar a natureza das carnes. Com efeito, traziam tanta elegância para comer, quanto em todo o resto. Pois primeiramente não tocavam nunca a

\footnotetext{
RIBEIRO, 2004, p. 201.

Idem, ibidem, p. 201-202.

Idem, ibidem, p. 202.

10 Idem, ibidem, p. 202-203.
} 
carne com as mãos, mas com os garfos, levavam-na até suas bocas alongando o pescoço e o corpo sobre seus pratos, que eram trocados com frequiência. Mesmo seus pães eram todos fatiados, sem que tivessem o trabalho de cortá-los e acredito que teriam muito desejado que fosse encontrada futuramente uma invenção com a qual não se tivesse a pena de mastigar. Pois pelo que pude ver, isto os ocupava muito, pois muito dentre eles tinham dentes artificiais, que retiraram antes de porem-se à mesa. ${ }^{11}$

Depois disto trouxeram a fruta, mas era o que havia de menos em seu natural, pois estava quase toda fantasiada em untagens, geleias líquidas e outras invenções: pois dizem que é muito prejudicial à saúde quando se a come assim como vem da árvore. ${ }^{12}$

[...] quanto às espadas, eram somente para a aparência, que delas não se serviam, a não ser quando queriam fazer-se de valentes, contra aqueles que não ousavam ou que não sabiam se defender. $O$ que eu acreditei facilmente, visto suas maneiras de agir, e também que tendo considerado as bainhas, bem vi que não estavam ali para suportar grandes golpes: eram todas muito lindamente feitas, umas douradas, outra adamascadas; quanto à lâmina, não era nem mais larga nem mais pesada do que um chicote; e tão perfumadas que ainda que tivessem forros de couro coberto com veludo, o cheiro não deixaria de penetrá-las, e de propagar-se; dizia-se que isto era o motivo por que os golpes eram favoráveis, pois não eram tão violentamente dados que deles se morresse; que se isso acontecesse, pelo menos a morte seria muito feliz, pois teria sido dada por uma tão bela espada. ${ }^{13}$

$\mathrm{Na}$ outra extremidade deste local havia muitas armas penduradas que guardavam muito religiosamente sua virgindade. Eram muito douradas, muito leves e delicadamente elaboradas: com efeito, estavam lá somente para exibição e não para o uso. Pois não há espada que ousasse penetrar uma coisa tão rica e tão curiosamente

\footnotetext{
11 RIBEIRO, 2004, p. 204-205.

12 Idem, ibidem, p. 206.

13 Idem, ibidem, p. 149.
} 
fabricada, de modo que os Senhores destas endossavam-nas somente pela extremidade; mais como marca de sua grandeza, e para fazer aparecer a generosidade de sua coragem, que por algum feito de armas que esperassem alcançar por meio destas. ${ }^{14}$

\section{A linguagem hermafrodita}

Nesta ruela iam as três pessoas que eu dizia acima, e começaram a invocar este ídolo por nomes que não se podem bem representar em nossa língua, pois toda a linguagem, e todos os termos dos Hermafroditas, são os mesmos que os Gramáticos chamam de gênero comum, e referem-se tanto ao macho quanto à fêmea; todavia desejando saber quais discursos faziam, um de seu séquito, de quem me aproximara, e que entendia bem o Italiano, me disse que eles davam mil louvores às suas perfeições, e entre outras, que louvavam muito a beleza e a brancura de suas mãos $[\ldots]^{15}$

[...] em volta das quais havia uma palavra latina que quer dizer em nossa língua companheiro de armas. ${ }^{16}$

Eu queria acabar de ver todo o resto desta história, mas vendo um dos domésticos que me pareceu de um modo bastante cortês aproximar-se de mim, pensei que seria melhor saber o que significava tudo isso; e julgando que ele entendia a língua Latina, como ouvira dizer aos outros algumas palavras aqui e acolá, roguei-lhe que me explicasse com a mesma linguagem estas figuras que estavam aqui representadas, o que ele se ofereceu para fazer livremente $[\ldots]^{17}$

[...] abrindo uma porta onde havia uma pequena cabina, na qual estavam alguns armários sobre alguns dos quais havia livros e sobre os outros vários papéis; nalguns haviam Pasquins, Sátiras, e outros tipos de poesias, e sobre os outros estavam as cópias das quais

\footnotetext{
14 RIBEIRO, 2004, p. 211.

15 Idem, ibidem, p. 151.

16 Idem, ibidem, p. 152.

17 Idem, ibidem, p. 153.
} 
falei acima, das quais ele me deu uma em Latim que depois traduzi em nossa língua, como podereis ver neste papel, se fazer a leitura for de vosso grado. E então, fazendo trazer um pequeno cofre, tirou um papel, onde encontramos o que se segue. ${ }^{18}$

Os livros que se lerão mais comumente, e dos quais tomar-seá assunto de exortação, serão Ovídio, Catulo, Tibério, Propércio, traduzidos em várias e diversas línguas, segundo o uso das nações. ${ }^{19}$

Os banquetes e festins se farão, de preferência à noite que de dia, com toda a superfluidade, prodigalidade, curiosidade e delicadeza possíveis, e segundo a invenção e opulência dos ricos presentes ou por vir poderá permitir, queremos que se use todo tipo de cristas e de línguas, entre outras dos Galos, dos Pavões e dos Rouxinóis $[\ldots]^{20}$

Porque os nossos têm entre si vários conluios, conspirações, intentos e empresas secretas, seja por amor, seja pelo Estado, nós lhes permitimos e temos permitido ter desde agora e para sempre alguma língua ou jargão composto segundo sua fantasia que eles nomearão com algum nome estranho, como Mesopotâmica, Pantagruélica e outros. Usarão também sinais ao invés de palavras, a fim de serem entendidos em seus pensamentos mais secretos, por seus consabedores, e sem serem descobertos. ${ }^{21}$

[...] começaram a invocar este ídolo por nomes que não se podem bem representar em nossa língua, pois toda a linguagem, e todos os termos dos Hermafroditas, são os mesmos que os Gramáticos chamam de gênero comum, e referem-se tanto ao macho quanto à fêmea $[\ldots]^{22}$

\footnotetext{
18 RIBEIRO, 2004, p. 156.

19 Idem, ibidem, p. 161.

20 Idem, ibidem, "No que concerne à polícia", p. 176.

21 Idem, ibidem, "No que concerne às relações sociais", p. 182.

22 Idem, ibidem, p. 151.
} 
Seus discursos serão o mais freqüentemente coisas inventadas, sem verdade ou sem qualquer aparência de razão e o ornamento de sua linguagem será renegar e blasfemar pausadamente, e com gravidade fazer várias imprecações e maldições e outras flores de nossa Retórica para sustentar ou para persuadir à mentira, e quando quiserem persuadir a uma coisa falsa, começarão por estas palavras: "A verdade é..."23

Por graça e privilégio especial queremos também que seja permitido a nossos súditos inventar os termos e as palavras necessárias para a civil conversação, os quais terão ordinariamente duplo sentido: um representando ao pé da letra o que eles tiverem vontade de dizer, outro, um sentido místico de volúpia que somente será entendido por seus semelhantes ou que terão sido seus legionários, com esta observação, que, pronunciando-o, o som seja doce, por medo de ofender a delicadeza de suas orelhas, com proibições de usar outros, qualquer substância, propriedade ou significação que possam ter do que quisermos dizer. E a fim de que a continuação não lhes possa trazer algum aborrecimento, nós estimamos ser muito a propósito mudá-los todos os anos, a fim de que, se com o tempo o vulgar os quiser usar, possam eles ter sempre alguma coisa de particular ${ }^{24}$.

Cada um poderá vestir-se segundo sua fantasia, por mais bizarra que possa ser a invenção, desde que o inventor tenha nele a virtude que nossos contrários chamam petulância [... $]^{25}$ (Grifo meu).

Cada um poderá vestir-se segundo sua fantasia, desde que seja bravamente, sublimemente e sem nenhuma distinção nem consideração sobre sua qualidade ou faculdade. Que se, no feitio, um tecido, por precioso que seja, não for enriquecido com supérfluos bordados em ouro, prata, pedrarias e pérolas, e mais freqüentemente sem decência, tenhamos tais trajes por vis, mesquinhos e indignos de serem vestidos em boas companhias, reputando nisto toda modéstia

\footnotetext{
23 RIBEIRO, 2004, "No que concerne às relações sociais", p. 180.

24 Idem, ibidem, "No que concerne às relações sociais", p. 182.

25 Idem, ibidem, "No que concerne à polícia", p. 177.
} 
por baixeza de coração e falta de espírito. [...] pois nesta Ilha o hábito faz o monge, e não o contrário. ${ }^{26}$ (Grifos meus).

\section{As ordenanças d'A ilha dos hermafroditas}

Nós permitimos também aos pais e às mães traficar suas crianças para servirem de sacrifício ao amor, desde que seja a algum grande que lhes dê boa recompensa e sobre o qual possam fundar uma bela esperança. ${ }^{27}$

Eis porque nós permitimos a todos os nossos oficiais de justiça e outros que serão do número de nossos mais fiéis e afeiçoados súditos, de tomar sem escrúpulos, julgar a partir da etiqueta, fingir algum déficit ou calar alguma coisa importante, supor falsos títulos, lembrar-se somente das razões daqueles a quem eles querem fazer justiça, ou seja, favorecer, ajustar e reformar as sentenças ou decretos que tiverem sido dados, declarar os segredos e opiniões da assembléia, omitir às enquetes e interrogatórios muitas coisas de assunto ousado, dar lição aos falsos testemunhos, prolongar o julgamento ou abreviálos segundo a utilidade de seus amigos e outras invenções necessárias ao devido exercício de seus encargos, sem que por isto eles devam apreender serem jamais condenados, ou temer nenhuma Mercuriale, pois em todas estas coisas estimamos que devemos usar da proporção Geométrica. Também retiramos as balanças de nossa justiça e lhes demos os olhos e mãos que devem ter. ${ }^{28}$

Aqueles que tiverem a administração de nossas finanças serão constrangidos e obrigados a escutar sobre todas as coisas estas duas regras, de subtração e de multiplicação, para ajudar-se de uma em suas receitas, e de outra na despesa. Também queremos que saibam aumentar os registros (Enquadrar as linhas, Determinar as somas totais, Supor viagens e outros itens) a fim de que em suas contas possam preparar um capítulo dos deniers contados, e não pagos, no qual incluirão também as

26 RIBEIRO, 2004, "No que concerne à polícia", p. 174-175.

27 Idem, ibidem, "No que concerne à justiça e oficiais deste Estado", p. 165.

28 Idem, ibidem, "No que concerne à justiça e oficiais deste Estado", p. 167. 
faturas das quais tiverem somente pago, no máximo, o quarto, ou o terço, como dons, recompensas, cauções, quitação de dívidas, pagamento de rendas, mandamentos e outros tipos de rendimentos, os quais todavia redigirão detalhadamente às custas deles, suporão não-valores, tirarão em segredo ordenanças não ordenadas, darão os deniers reais com juros, câmbio e recâmbio, os quais serão em seu proveito e não àquele do Príncipe, a serviço de quem estarão. ${ }^{29}$

Que se houver algum marido que tenha ciúmes de sua mulher, ainda que mereça alguma punição por um tão grande crime, nós lhe permitimos no entanto trazer a chave do que suas mulheres tiverem a fechadura, de mantê-las confinadas o mais que poderão, desde que haja alguma pequena abertura por onde possa entrar a chuva de Danaé. Entendemos que aqueles ou aquelas que eles lhes darão como guardas ou espiões lhes sirvam de meios para corrompê-las. Queremos semelhantemente que as mulheres não se detenham em tudo o que lhes poderão dizer seus ditos maridos, mas dêem-se sempre bom tempo o mais que puderem; aconselhamos todavia de comportar-se o mais secretamente possível, de medo que não lhes sobrevenha apoplexia acidental ou algum mal supernatural. ${ }^{30}$

E ainda que tenhamos o casamento por coisa ridícula e inteiramente contrária a nossos desejos e vontades, dissipando as afeições mais freqüentemente do que lhes conservando, todavia, como ele traz comodidades ao amor de um segundo, permitimos seu uso; além do que, sob esta cobertura, as coisas, que de outro modo seriam divulgadas a todo mundo, se metem mais facilmente encobertas. ${ }^{31}$

Nos anos em que o trigo e o vinho forem mais raros que de costume, principalmente nos países onde não existam em grande quantidade, permitiremos aos nossos armazená-los e vendê-los somente em situação extrema, a fim de tirar mais facilmente todo o mau sangue do público que vem a eles durante os anos de abundância. ${ }^{32}$

29 RIBEIRO, 2004, "No que concerne à justiça e oficiais deste Estado", p. 168.

30 Idem, ibidem, "No que concerne à justiça e oficiais deste Estado", p. 164.

31 Idem, ibidem, "No que concerne à justiça e oficiais deste Estado", p. 166.

32 Idem, ibidem, "No que concerne à polícia", p. 172. 
Ainda que tenhamos a caridade por pura tolice, como uma invenção que serve somente para esvaziar as bolsas, que queiramos que as nossas estejam sempre plenas, todavia, porque ela tem reputação junto à gente e que faz-se caso daqueles que a abraçam, aconselhamos aos mais avisados dentre os nossos a assistir e tomar o partido de um pobre contra um rico, o qual, no entanto, não será tão apoiado e favorecido quanto eles, a fim de que ajudando a um eles possam despojar o outro e que sua avareza lhes traga o renome de liberalidade. ${ }^{33}$

[...] nós que queremos viver tanto quanto se possa as naturais inclinações às quais somos naturalmente dados, sem forçá-las nem constranger de sorte e maneira que seja $[\ldots]^{34}$

No que concerne aos incestos do pai com a filha, do irmão com a irmã, do genro com a sogra, e outros, que os loucos e desavisados estimam tamanho crime, queremos e entendemos que se possa usar de toda franqueza e liberdade, contanto que isto concirna e aumente em proporção as famílias, se alguma consangüinidade puder ser distinguida entre eles. ${ }^{35}$

Eis porque não temos por crime o homicídio quando o inimigo tiver sido pego à sua desvantagem; ao contrário, queremos que aqueles que tiverem tido a segurança de vingar-se de alguma injúria, por menor que tenha sido, possam caminhar com a cabeça erguida frente a todos, com a reputação de um galante e valente Hermafrodita. ${ }^{36}$

33 RIBEIRO, 2004, "No que concerne à polícia", p. 177.

34 Idem, ibidem, "No que concerne às relações sociais", p. 186.

35 Idem, ibidem, "No que concerne à justiça e oficiais deste Estado", p. 165.

Idem, ibidem, "No que concerne à justiça e oficiais deste Estado", p. 163. 
Se eles se reconciliarem uns com os outros, queremos que seja somente em aparência e que todos os seus abraços sejam laços que estreitam mais indissoluvelmente a sua inimizade $[\ldots]^{37}$

Nós reputamos a boa aparência em todas as coisas muito mais do que a ação, porque aquela esconde mais atos com menos pena. ${ }^{38}$

Referências

BAYLE, Pierre. Dictionnaire historique et critique. Roterdam: J. Leers, 1696-97 (artigo Salmacis). 2 tomos, 4 volumes.

DUBOIS, Gilbert. Introduction. In: THOMAS, Artus. L'Isle des Hermaphrodites. Édition, introduction et notes par Claude-Gilbert DUBOIS. Genève: Droz: 1996.

DUBOIS, Gilbert. La première anti-utopie française: Les Hermaphrodites, 1605. In: Utopia: mitos e formas. Lisboa: Fundação Calouste Gulbenkian (Acarte), 1993.

DUBOIS, Gilbert. L'Hermaphrodite: une allégorie énigmatique et son utilisation sous le règne d'Henri IV. In Cahiers de Littérature du XVII siècle, n 9, 1987; "Horrible Sphinx et peau de panthère", in Prose et prosateurs de la Renaissance (Mélanges offerts à Robert Aulotte). Paris: S.E.D.E.S., 1988.

DUBOIS, Gilbert. Le sauvage et l'hermaphrodite. In: La rencontre des imaginaires entre Europe et Amériques. Paris: L'Harmattan, 1993.

DUBOIS, Gilbert. Les références culturelles antiques dans L'île des Hermaphrodites (circa 1605). In: Euphrosyne, n. 26. Lisboa: CEC, 1998.

DUBOIS, Gilbert. Un aspect de la littérature utopique dans les lettres françaises sous le règne d'Henri IV. In: Avènement d'Henri IV, Quatrième Centenaire. Colloquio IV, Agen-Nérac, 1990.

ELIAS, Norbert. Formação e evolução da sociedade de corte em França. In: A sociedade de corte. Lisboa: Estampa: 1995, p. 121-181.

37 RIBEIRO, 2004, "No que concerne às relações sociais", p. 188-189.

38 Idem, ibidem, "Ordenanças sobre o fato da religião", p. 158. 
ERLANGER, Philippe. Henri III. Paris: Gallimard, 1948.

RIBEIRO, Ana Cláudia Romano. A Ilha dos Hermafroditas (Paris, 1605) em seu ambiente histórico. Campinas, Revista Morus, n 1, p. 147- 65, 2004.

RIBEIRO, Ana Cláudia Romano. A Ilha dos Hermafroditas: viagem à França especular de Henrique III. Dissertação de Mestrado em Teoria e História Literária. Instituto de Estudos da Linguagem, Universidade Estadual de Campinas. Campinas, 2005.

THOMAS, Artus. L'Isle des Hermaphrodites. Édition, introduction et notes par Claude-Gilbert DUBOIS. Genève: Droz: 1996. 